\title{
JAUNIEŠU ATPAKAḶMIGRĀCIJA EIROPĀ: IEGUVUMI UN IZAICINĀJUMI
}

\section{Zaiga Krišjāne, Elīna Apsīte-Beriṇa, Māris Bērziṇš, Guido Sechi, Toms Skadiņš}

Latvijas Universitāte, G̣eogrāfijas un Zemes zinātṇu-fakultāte, e-pasts: zaiga.krisjane@lu.Iv

\begin{abstract}
Anotācija. Pētījumi par jauniešu migrācijas formu daudzveidību Eiropā raksturo migrācijas dažādību. Pētījuma mērḳis ir atspoguḷot jauniešu individuālās migrācijas pieredzes būtiskākās tendences, atklājot remigrantu ieguvumus un izaicinājumus. Pētījumā izmantoti dati no ES programmas Apvārsnis 2020 (Horizon 2020) projekta YMOBILITY, kas norisinājās laika periodā no 2015. līdz 2018. gadam devināās Eiropas Savienības valstīs, tostarp Latvijā. Rakstā apkopota migrācijas pieredze un ieguvumi, ko sniedz starptautiskā migrācija, un kas ir ieguldījums jauniešu personības izaugsmē.
\end{abstract}

Atslēgas vārdi: Jauniešu migrācija, migrācijas pieredze, remigrācija, Eiropa. 


\section{Ievads}

Mūsdienās migrācijai Eiropā raksturīga migrācijas formu un plūsmu daudzveidības palielināšanās. To ietekmē labklājības līmeņa atškirīibas starp valstīm, darba tirgus ierobežojumu atcelšana, studiju iespējas, zemas transporta un komunikāciju izmaksas, migrantu neformālo un formālu tīklu attīstība un valstu un darba devēju politika imigrantu nodarbināšanā (Hooghe et al. 2008; King 2012).

Migrācijas pētniecībā palielinās interese par remigrācijas procesiem. Atpakaḷmigrācijas pētījumus apgrūtina fakts, ka teorētiskā pieeja migrācijas pêtījumos sākotnēji tika veidota, lai skaidrotu migrāciju kā vienreizēju notikumu, bet ne atkārtotu vai vairākkārtēju notikumu. Pêtījumi par atpakaḷmigrāciju un to ietekmējošiem galvenajiem faktoriem aktualizējās 20.gs. 70.-80. gados saistībā ar viesstrādniekiem Eiropā (Gmelch 1980; Cassariono 2004). Migrācijas pētījumos tradicionāli īpaša uzmanība ir bijusi pievērsta ekonomiskajiem un ar darba tirgu saistītajiem jautājumiem. Mūsdienās migrācijas pētījumos vairāk tiek vērtēta neformālo sociālo tīklu, giimenes un draugu loma. Tāpat tiek skatîts, kā migranta transnacionālā pieredze ietekmē migrāciju un migrācijas lēmumu pieņemšanas procesu.

Iepriekšējos pētījumos bieži tika vērtēti darba tirgus ieguvumi uzņemošajās jeb galamērķa valstīs (Anderson et al. 2006; Clark, Drinkwater 2008; Dustmann et al. 2011; Pollard et al. 2008), kamēr daudz mazāk ir zināms par ietekmi tajās valstīs un reǵionos, no kuriem cilvēki izcelıja, un migrantu nodarbinātību pēc atgriešanās (Lang et al. 2016). Tāpat pētījumi parāda, ka migranti bieži atstāj savas valstis ar ieceri kādreiz tajās atgriezties un ka migrācija ir tikai pagaidu posms viņu dzīvē (Vertovec 2009). Jauniešu atgriešanās savās izcelsmes valstīs ir visai maz pētìta (King 2018). Pētījuma mērḳis ir atspoguḷot jauniešu migrācijas pieredzes būtiskākās tendences, parādot migrantu ieguvumus un izaicinājumus.

\section{Atgriešanās kā mobilitātes forma}

Dažādas mobilitātes formas ir aizstājušas ilgtermiņa migrāciju. Vienkāršotais priekšstats par migrāciju, kam seko atgriešanās, ir aizstāts ar izpratni par migrāciju kā dalıu no ilgāka mobilitātes procesa, kas var sasaistīt starptautisko ar iekšzemes pārvietošanos (King, Skeldon 2010), kā arī ar īslaicīgu mobilitāti un pārvietošanās secību. Līidz ar to daudzveidīgās mobilitātes formas ir jāskata līdztekus pastāvīgai migrācijai (Hatton, Williamson 1998; Favell et al. 2007), ko parasti raksturo nevis vienkārša pārvietošanās no vienas vietas uz otru, bet gan sarežğīts pārvietošanās kopums, uz priekšu, atpakaḷ un tâlāk (Skeldon 2012). Tas notiek migrācijas sistēmās, kas savieno valstis un reǵionus (Fawcett, 1989). Lēmumu par atgriešanos bieži ietekmē ekonomiski apsvērumi, kas jāskata kā ieguvums no ārvalstīs iegūtajām prasmēm un dzīvošanas izmaksām (dzīves dārdzība, mājoklis) dažādās vietās (Dustmann, Weiss 2007; Dustmann et al. 2011). Papildus šiem ekonomiskajiem apsvērumiem, atgriešanās migrāciju ietekmē arī bažas par drošību, bērnu izglītošanu, veselību, kultūras atstumtību un sociālo integrāciju (Cassarino 2004) vai atsvešināšanos (Gmelch 1980), kā arī migrantu ilgas pēc mājām (Kḷave, Šūpule 2015; Sandu et al. 2017). Šajā skatījumā 
atgriešanās migrācija var nebūt migrācijas procesa beigas, bet gan atkārtots posms, tālāka pārvietošanās vai cirkulārās migrācijas priekštecis (Cassarino 2004; King 2012). Transnacionālisma laikmetā termini "atgriešanās migrācija", "pagaidu migrācija" un "cirkulārā migrācija" pārklājas, un robežas starp tām dažreiz ir neskaidras (Carling, Erdal 2014). Atgriešanās vizītes izcelsmes valstī vai arī cirkulārā migrācija tiek uztverta kā transnacionāla prakse, kas vairākos veidos mijiedarbojas ar iespējamo atgriešanos (Burrell 2009; King et al. 2013; Lulle 2014). Faists un kolẹgi ( Faist et al. 2013) norāda, ka transnacionālisms tiek saprasts kā transnacionāla prakse četrās "transnacionālās dz̄ives sfērās" - gimenes, sociokultūras, ekonomiskajā un politiskajā. Mūsdienu pētījumos par migrantu tīkliem un transnacionālismu tiek uzsvērts, ka tehnikas sasniegumi ir ḷāvuši migrantiem veidot un uzturēt saiknes, kas savieno izcelsmes un galamērķa valstis ar lētāku un ātrāku transportu, internetu, mobilajiem sakariem un satelīta televīziju, tāpat to ḷāvuši arī institucionālie ietvari un neformālie kanāli naudas un preču pārsūtiššanai (Larsen et al. 2006). Tas ir paplašinājis migrantu iespējas veicināt savu piederību, veidot "divkāršu identitāti", iegūt dubultpilsonību, ceḷot turp un atpakaḷ, strādāt un vienlaikus veikt uzṇēmējdarbību tālās vietās (Portes et al. 1999; Cassarino 2004; Vertovec 2009; de Haas 2005).

\section{Jauniešu migrācija}

Aplūkojot gados jauno iedzīvotāju migrāciju, jāṇem vērā svarīgs posms pašu jauniešu dzīvē, kad notiek pāreja no jauniešu uz pieaugušo statusu. Šajā periodā jaunieši ir ieguvuši izglîtību, sāk darba gaitas, veido ǵimenes (Corijn, Klijzing 2001, King 2018). Tas jāṇem vērā, aplūkojot migrantu lēmumu atgriezties. Tāpat jauniešu migrācijai, salīdzinot ar vecāka gadagājuma migrantu grupām, biežāk ir raksturīgs pagaidu raksturs. (Tverdostup, Masso 2016)

Turklāt atgriešanās var arī nebūt migrācijas secīgs noslēgums, bet gan jaunas migrācijas priekštecis. Tas notiek tāpēc, ka iepriekšējā (uzkrātā) migrācijas pieredze un sociālie tīkli var būt pamats, lai turpmāk dotos uz ārzemēm (Balaž et al. 2004). Tomēr joprojām vērojams informācijas trūkums par jaunākajām atgriešanās migrācijas tendencēm Eiropā un it īpaši postsociālisma valstīs Centrālajā un Austrumeiropā.

\section{Dati un metodes}

Pētījumā izmantoti dati no ES programmas Apvārsnis 2020 (Horizon 2020) projekta YMOBILITY, kas norisinājās laika posmā no 2015. līdz 2018. gadam deviṇās Eiropas Savienības valstīs, tostarp Latvijā. Projekts, kura laikā tika pētīta jauniešu migrācija Eiropā, fokusējās uz jauniešu pieredzi mikro līmenī, darba tirgus un reǵionu iespējām, piesaistot vai zaudējot cilvēkus vecumā no 16 līdz 35 gadiem. Latvija, Slovākija un Rumānija pārstāvēja Austrumeiropas valstu grupu, no kurām cilvēki pārsvarā emigrē. Dienvideiropas valstis - Itālija, Spānija, kā arī Īrija ir gan migrantus sūtošās, gan uzṇemošās valstis, bet Lielbritānija, Vācija un Zviedrija tika izraudzītas kā ekonomiski attīstîtākās valstis, kuras piesaista migrantus. Rakstā iekḷautā rezultātu daḷa 
raksturo būtiskāko jauniešu migrācijas pieredzi, kas atspoguḷo tendences, kas parāda dažādu jauniešu migrantu grupu ieguvumus un izaicinājumus.

Projekta ietvaros šajās valstīs tika aptaujāti 30000 respondenti vecumā no 16 līdz 35 gadiem, no kuriem 3851 bija atpakal̦migranti. Projekta ES vecajās dalībvalstīs 2944 tika aptaujāti remigranti, bet 907 - jaunajās ES dalībvalstīs.

Lai vispusīgāk izzinātu migrantu individuālo pieredzi, tika veiktas arī padziḷinātas strukturētās intervijas ar remigrantiem pēc viṇu atgriešanās dzimtenē. Remigranti tika izraudzīti atbilstoši dzīvesvietai: valstu galvaspilsētu un perifêros regionos. Tālāk tie tika atlasīti pēc iepriekšejēās nodarbošanās ārvalstīs: studenti, augsti kvalificēti speciālisti un citās profesijās strādājošie.

Remigrantu vidū dominējošă ir vecuma grupa 26-35 gadi. ES vecajās dalībvalstīs respondentiem nedaudz lielāks ir vīriešu īpatsvars $(50,4 \%)$, bet jaunajās dalībvalstīs lielāks ir sieviešu īpatsvars (53,4\%). Pēc ğimenes stāvokḷa atgriezušos vidū abās valstu grupās dominē vieni un bez bērniem dzīvojošie (49,7\% un attiecīgi 45,2\% jaunajās ES dalībvalstīs). Nākamā grupa ir precējušies vai ar partneri kopā dzīvojošie, kuriem ir bērni. Lielākas atšķirības ir vērojamas, raksturojot remigrantus pēc izglīitības līmeņa. Jauno dalībvalstu respondentu vidū lielākais īpatsvars ir jauniešiem ar vidējo izglītîbu $(38,4 \%)$, bet ES vecajās dalībvalstīs - respondentiem ar pirmā līmeņa augstāko izglītîbu $(35,7 \%)$. Vidējais uzturēšanās ilgums ārzemēs abām grupām būtiski neatšķiras. Visiem remigrantiem tas vidēji ir 27.58 mēneši.

1. tabula. Respondentu remigrantu raksturojums

\begin{tabular}{|c|c|c|c|c|}
\hline Pazīme & & $\begin{array}{l}\text { Atgriezušies ES } \\
\text { vecajās dalībvalstīs }\end{array}$ & $\begin{array}{l}\text { Atgriezušies } \\
\text { ES jaunajās } \\
\text { dalībvalstīs }\end{array}$ & $\begin{array}{l}\text { Visi } \\
\text { kopā }\end{array}$ \\
\hline \multirow[t]{2}{*}{ Vecums } & $16-25$ & $37,3 \%$ & $31,5 \%$ & $35,9 \%$ \\
\hline & $26-35$ & $62,7 \%$ & $68,5 \%$ & $64,1 \%$ \\
\hline \multirow[t]{2}{*}{ dzimums } & vīrieši & $50,4 \%$ & $46,6 \%$ & $49,5 \%$ \\
\hline & sievietes & $49,6 \%$ & $53,4 \%$ & $50,5 \%$ \\
\hline \multirow[t]{5}{*}{$\begin{array}{l}\text { G̣imenes } \\
\text { stāvoklis }\end{array}$} & viens/-a bez bērniem & $49,7 \%$ & $45,2 \%$ & $48,7 \%$ \\
\hline & vientulaiais vecāks & $2,9 \%$ & $4,6 \%$ & $3,3 \%$ \\
\hline & $\begin{array}{l}\text { precējies (-usies) vai dzīvo ar } \\
\text { partneri }\end{array}$ & $18,7 \%$ & $12,8 \%$ & $17,3 \%$ \\
\hline & $\begin{array}{l}\text { precējies (-usies) vai dzīvo ar } \\
\text { partneri un ar bērniem }\end{array}$ & $27,5 \%$ & $32,4 \%$ & $28,6 \%$ \\
\hline & škīiries vai atraitnis & $1,2 \%$ & $5,0 \%$ & $2,1 \%$ \\
\hline \multirow[t]{5}{*}{$\begin{array}{l}\text { Izglītības } \\
\text { līmenis }\end{array}$} & pamatizglītība & $1,6 \%$ & $3,4 \%$ & $2,0 \%$ \\
\hline & vidējā izglītība & $9,0 \%$ & $38,4 \%$ & $15,9 \%$ \\
\hline & profesionālā vidējā izglītība & $22,6 \%$ & $19,4 \%$ & $21,8 \%$ \\
\hline & pirmā līmeņa augstākā izglītîba & $35,7 \%$ & $20,5 \%$ & $32,1 \%$ \\
\hline & otrā līmeņa augstākā izglīitîba & $31,1 \%$ & $18,3 \%$ & $28,1 \%$ \\
\hline
\end{tabular}

\section{Ieguvumi un izaicinājumi Eiropas jauniešu atpakaḷmigrācijā}

Lai raksturotu migrācijas pieredzi, tika izmantots respondentu vērtējums par viņiem svarīgiem ieguvumiem 5 ballu Likarta skalā, sākot ar vērtējumu 1, kas liecina, 
ka respondentam tas nav svarīgs, līdz 5, kas respondenta vērtējumā tiek uzskatīts par l’oti svarīgu. Lai salīdzinātu jauno un veco ES dalībvalstu migrācijas pieredzes atškirīgo vērtējumu, tika izmantots neparametriskais Mann-Whitney $U$ tests, kas parāda, vai atbilžu atškirīības starp šīm abām grupām ir būtiskas. Respondentu atbildes tika ranžētas pēc to vidējās vērtības.

Pieredze un ieguvumi, ko sniedz starptautiskā migrācija, ir ieguldījums katra cilvēka individuālajā kapitālā. Pētījuma rezultāti par jauniešu migrāciju Eiropā parāda, ka remigranti gan jaunajās, gan vecajās ES dalībvalstīs visaugstāk novērtē to, ka ir ieguvuši lielāku pārliecību par savām spējām. Te nav vērojamas būtiskas atškirīibas starp abām valstu grupām. Tāpat nav ievērojamu atšķirību, analizējot svešvalodu apguvi, lai gan, nosakot svešvalodu prasmes pēc nozīmības, jaunajās un vecajās dalībvalstīs tās tiek vērtētas atšḳirīgi. Jaunajās ES valstīs tās ierindo 3. vietā. Lai gan pastāv vērā ņemamas atšķirības, salīdzinot vidējo vērtējumu, abās valstu grupās remigranti augstu novērtē, ka ārzemēs ir iegūtas spējas tikt galā ar jauniem izaicinājumiem. Būtiski atšḳiras vērtējums, kas raksturo spējas adaptēties jaunā kultūrvidē, vērtējums par jaunu prasmju ieguvi un kvalifikācijas apguvi. Iegūtās migrācijas pieredzes vērtējums parāda, ka tai ir svarīga nozīme remigranta pašapziņas un pašpārliecinātības nostiprināšanā.

2. tabula. Remigrantu migrācijas pieredzes vidējais vērtējums (1- nav svarīgi līdz 5 - ḷoti svarīgi)

\begin{tabular}{|l|c|c|c|c|c|}
\hline \multicolumn{1}{|c|}{ Ieguvumi } & $\begin{array}{c}\text { Vecajās ES } \\
\text { dalībvalstīs }\end{array}$ & $\begin{array}{c}\text { Jaunajās ES } \\
\text { dalībvalstīs }\end{array}$ & \multicolumn{2}{|c|}{ Rangi } & $\begin{array}{c}\text { Atškirīību } \\
\text { būtiskums Mann- } \\
\text { Whitney U tests }\end{array}$ \\
\hline $\begin{array}{l}\text { Kvalifikācijas } \\
\text { iegūšana }\end{array}$ & 3,43 & 3,06 & 6 & 6 &, $\mathbf{0 0 0}$ \\
\hline Jaunu prasmju apguve & 4,06 & 3,87 & 4 & 5 &, $\mathbf{0 0 0}$ \\
\hline $\begin{array}{l}\text { Spēja tikt galā ar } \\
\text { jauniem } \\
\text { izaicinājumiem }\end{array}$ & 4,27 & 4,19 & 1 & 2 &, $\mathbf{0 3 6}$ \\
\hline Svešvalodu apguve & 4,03 & 3,99 & 5 & 3 &, 381 \\
\hline $\begin{array}{l}\text { Lielāka pārliecība par } \\
\text { sevi }\end{array}$ & 4,20 & 4,20 & 2 & 1 &, 705 \\
\hline $\begin{array}{l}\text { Spēja adaptēties jaunā } \\
\text { kultūrvidē }\end{array}$ & 4,17 & 3,89 & 3 & 4 &, $\mathbf{0 0 0}$ \\
\hline
\end{tabular}

Remigrantu interviju rezultāti parāda, ka migrācijas laikā iegūtajai individuālajai pieredzei kopumā ir pozitīvs vērtējums. Svešvalodas apgūšanu un pilnveidošanu ārzemēs vairums remigrantu gan jaunajās, gan vecajās ES dalībvalstīs vērtē pozitīvi un uzskata par ieguvumu. Augstu tiek vērtēta pašapziņa, kas gūta, dzīvojot ārzemēs, un tā tiek uzskatīta par vienu galvenajiem ieguvumiem līdzās svešvalodu zināšanām. Ārzemēs gūtā pieredze dod iespēju sazināties ar cilvēkiem no citām valstīm. Apgūstot citas kultūras, tie, kuri ir atgriezušies, ir tolerantāki pret līdzcilvēkiem, apkārtni un notikumiem pasaulē.

Tai pašā laikā citu ieguvumu pozitīvais vērtējums ir atšķirīgs remigrantiem ar dažādu nodarbinātības statusu. Bijušie studenti ir ne tikai uzlabojuši valodas prasmes, bet arī apguvuši studiju programmas, kas sniedz lielākas starptautiskās karjeras iespējas. 
Aptaujātie remigranti kopumā norādīja, ka vini ir noslēguši līdzšinējo migrācijas posmu un ka tuvākā gada laikā plāno palikt savā izcelsmes valstī. Remigranti, kuri ārvalstīs strādājuši, norāda, ka migrācijas pieredze ir nodrošinājusi ar dažādām (gan formālām, gan neformālām) prasmēm un iemaṇām, kas izrādījušās noderīgas pēc atgriešanās dzimtenē. Daudzi norāda uz lielāku pašpārliecinātību par sevi un spējām gūt panākumus, kā arī darboties nepazīstamā vidē un sazināties ar svešiem cilvēkiem. Palielinājusies personiskās kompetences izpratne un paḷāvība uz saviem spēkiem, kas jāvērtē kā pozitīvs migrācijas ieguvums.

Augsti kvalificēti remigranti, kuriem migrēšanas laikā bija galamērḳa valsts valodas prasme labā līmenī, norādīja uz profesionālās karjeras izaugsmes iespējām un iespēju darboties globālā līmen̄i. Daudzi intervijās apliecina, ka pēc atgriešanās vinuu starptautiskā pieredze darba tirgū tikusi novērtēta. Daudzos gadījumos svešvalodu prasme, galvenokārt angḷu valodas zināšanas, uzskatītas par priekšrocību.

Lai gan dažās intervijas tika minēta arī neapmierinātība ar dzīves apstākḷiem ārvalstīs, nespēja pieņemt atšķirīgo, tomēr remigranti šo dzīves posmu neuzskata par neveiksmīgu, bet gan norāda, ka tas vinuus ir pamudinājis atgriezties dzimtenē un pārvērtēt dzimtās vietas un sociālo kontaktu nozīmi. Tāpat tiek uzsvērta ārvalstīs iegūto neformālo prasmju vai "mīksto prasmju" nozīme (piemēram, tolerance, spēja uzṇemties risku un uzṇēmējdarbības spējas).

Ārvalstīs iegūtā personiskā un sociālā pieredze tika īpaši novērtēta kā personīgas izaugsmes forma. Starptautiskā pieredze sniedza jauniešiem iespēju dzīvot vieniem neatkarīgi no vecākiem - un iespēju pārbaudīt savas prasmes. Šis aspekts bieži vien ir saistîts ar plašāku skatījumu, kas izveidojies, dzīvojot ārpus ierastās "komforta zonas", īpaši lielajās Eiropas pilsētās.

\section{Pateicība}

Raksts izstrādāts ar projekta „YMOBILITY” (granta nr. 649491) atbalstu.

\section{Atsauces}

Anderson, B., Ruhs, M., Rogaly, B., Spencer, S.. (2006). Fair Enough? Central and East European Migrants in Low-wage Employment in the UK. COMPAS, Oxford University.

Balaž, V., Williams, A.M., Kollar, D. (2004). Temporary versus permanent youth brain drain: economic implications. International Migration, 42(4), 3 - 34.

Burrell, K. (2009). Introduction. Burrell K (ed.) Polish Migration to the UK in the 'New' European Union. Farnham Ashgate, 1 - 22.

Carling, J., Erdal, M. B. (2014). Return Migration and Transnationalism: How Are the Two Connected? International Migration, 52(6), 2 - 12.

Cassarino, J.P. (2004). Theorising Return Migration: The Conceptual Approach to Return Migrants. International Journal on Multicultural Societies (IJMS), 6(2), 253 - 279.

Clark, K., Drinkwater, S. (2008). The labour-market performance of recent migrants. Oxford Review of Economic Policy, 24(3), 496 - 517.

Corijn, M., Klijzing, E. (2001). Transitions to adulthood in Europe: Conclusions and discussion. Transitions to adulthood in Europe. Springer Netherlands, 313 - 340.

De Haas, H. (2005). International Migration, Remittances and Development: myths and facts. Third World Quarterly, 26 (8), 1269 - 1284. 
Dustmann, C. and Weiss, Y. (2007). Return Migration: Theory and Empirical Evidence from the U.K. British Journal of Industrial Relations, 45(2), 236 - 256.

Dustmann, C., Fadlon, I. and Weiss, Y. (2011). Return migration, human capital accumulation and the brain drain. Journal of Development Economics, 95(1), 58 - 67.

Faist, T., Fauser, M., Reisenauer, E. (2013). Transnational Migration. Cambridge, Polity Press.

Favell, A., Feldblum, M., Smith, M. P. (2007). The human face of global mobility: A research agenda. Society, 44(2), $15-25$.

Fawcett, J. T. (1989). Networks, linkages, and migration systems. International Migration Review, 23(3), 671-680.

Gmelch, G. (1980). Return migration. Annual Review of Anthropology, 9, 135 - 159.

Hatton, T. J. and Williamson, J. G. (1998). The age of mass migration: Causes and economic impact. Oxford University Press, Oxford.

Hooghe, M., Trappers, A., Meuleman, B., Reeskens, T. (2008). Migration to European countries: A structural explanation of patterns, 1980-2004. International Migration Review, 42(2), 476 - 504.

King, R. (20120. Geography and migration studies: retrospect and prospect. Population, Space and Place, 18(2), 134-153.

King, R. (2018). Theorising new European youth mobilities. Population, Space and Place, e2117. https://doi.org/10.1002/psp.2117

King, R., Lulle, A., Mueller, D., Vathi, Z. (2013). Visiting friends and relatives and its links with international migration: a three-way comparison of migrants in the UK. Willy Brandt series of Working Papers in International Migration and Ethnic Relations 4/13.

King, R., Skeldon, R. (2010). 'Mind the Gap!' Integrating approaches to internal and international migration. Journal of Ethnic and Migration Studies, 36(10), 1619 - 1646.

Kḷave, E., Šūpule, I. (2015). Remigrācijas procesa analīze: politika un prakse. Mieriņa I. (red.) Latvijas emigrantu kopienas: cerību diaspora. Rīga, Filozofijas un sociologijas institūts. 194 - 209.

Lang, T., Glorius, B., Nadler, R. and Kovács, Z. (2016). Introduction: Mobility Against the Stream? New Concepts, Methodological Approaches and Regional Perspectives on Return Migration in Europe. Return Migration and Regional Development in Europe. Palgrave Macmillan UK. 1 - 22.

Larsen, J., Axhausen, K. W., Urry, J. (2006). Geographies of social networks: meetings, travel and communications. Mobilities, 1(2), $261-283$.

Lulle, A. (2014). Spaces of encounter-displacement: contemporary labour migrants' return visits to Latvia. Geografiska Annaler, B Series, 96(2), 127-140.

Pollard, N., Latorre, M., Sriskandarajah, D. (2008). Floodgates or Turnstiles?: Post-EU Enlargement Migration Flows to (and from) the UK. Institute for Public Policy Research.

Portes, A., Guarnizo, L.E., Landolt, P. (1999). The study of transnationalism: Pitfalls and promises of an emergent research field. Ethnic and Racial Studies, 22(2), 217 - 237.

Sandu, D., Toth, G., Tudor, E. (2017). The nexus of motivation-experience in the migration process of young Romanians. Population, Space and Place, e2114. https://doi.org/10.1002/psp.2114

Skeldon, R. (2012). Going round in circles: circular migration, poverty alleviation and marginality. International Migration, 50(3), 43 - 60.

Tverdostup, M., Masso, J. (2016). The labour market performance of young return migrants after the crisis in CEE countries: the case of Estonia, Baltic Journal of Economics, 16(2), 192 - 220.

Vertovec, S. (2009). Transnationalism. London \& New York, Routledge.

\section{Summary}

Research on the variety of youth migration forms in Europe characterizes the diversity of migration. The aim of this study is to disclose the most important trends in the experience of individual youth migration, revealing the gains and challenges of the return migrants. This study uses data from the EU program Horizon 2020 project YMOBILITY, which took place from 2015 to 2018 in nine European Union countries, including Latvia. The article summarizes the experience of migration and the gain of international migration and what contributes to the growth of young people's personalities. 